\title{
RADIOCARBON DATING OF THE STONE AND BRONZE AGE SITES IN PRIMORYE (RUSSIAN FAR EAST)
}

\author{
YAROSLAV V. KUZMIN, ${ }^{1}$ LYOBOV A. ORLOVA, ${ }^{2}$ LEOPOLD D. SULERZHITSKY ${ }^{3}$ \\ and A. J. T. JULL4
}

\section{INTRODUCTION}

The first results of radiocarbon dating of the ancient sites in the Russian Far East were published early in the 1960s (Okladnikov 1964). We now have enough data to establish the main features in the ${ }^{14} \mathrm{C}$ chronology of the Stone and Bronze Age cultures in Primorye, one of the archaeologically wellstudied regions of the Russian Far East.

The 49 dates described here were sampled from 19 sites and analyzed at different laboratories at the following institutions: The University of Arizona, Tucson (AA); Institute of Geology, Novosibirsk (SOAN); Geological Institute, Moscow (GIN); Moscow State University (MGU); Institute of Archaeology, St. Petersburg (RUL, LE); Northeastern Complex Research Institute, Magadan (MAG); Institute of Geochemistry and Physics of Minerals, Ukrainian Academy of Sciences, Kiev (Ki); Institute of Geography, Moscow (IGAN). All the Russian laboratories are part of the Russian Academy of Sciences.

The materials dated are mainly charcoal collected during excavations, but we also dated other materials, such as birch bark, wood, bones (both human and animal), humus and seeds. Except for samples indexed AA-, which were dated by accelerator mass spectrometry (AMS), all samples were dated using liquid scintillation counting (LSC). Neolithic and Bronze Age dates were calibrated according to standard tables compiled by Klein et al. (1982) and Stuiver and Pearson (1986). Figure 1 shows the locations of sites in this study.

We report here only dates that correspond well to archaeological contexts (Krushanov 1989). Some disagreements of ${ }^{14} \mathrm{C}$ ages with the expected archaeological contexts are discussed in the comments.

\section{THE PALEOLITHIC}

1. IGAN-341

$32,570 \pm 1510$

Bones of horse and mammoth, from Geographical Society cave $\left(42^{\circ} 52^{\prime} \mathrm{N}, 133^{\circ} 00^{\prime} \mathrm{E}\right)$, depth $60-80$ $\mathrm{cm}$ below surface. Collected and submitted by N. K. Vereschchagin.

Comment (Y.K.): Vasiljevsky (1987) believes that artifacts lie below the dated level. This conjecture remains to be confirmed.

2. Ki-3502

$15,300 \pm 140$

Small charcoal fragments from Suvorovo $4\left(44^{\circ} 15^{\prime} \mathrm{N}, 135^{\circ} 19^{\prime} \mathrm{E}\right)$, from $25-30 \mathrm{~cm}$ below surface in Squares KH-9, TS-9, collected August 1989 by S. Gladyishev and A. Tabarev, submitted September 1989 by Y. Kuzmin.

\footnotetext{
${ }^{1}$ Pacific Institute of Geography, Far Eastern Branch of the Russian Academy of Sciences, Radio Street 7, Vladivostok 690041 Russia

${ }^{2}$ Institute of Geology, Russian Academy of Sciences, Universitetsky Prospect 3, Novosibirsk 630090 Russia

${ }^{3}$ Geological Institute, Russian Academy of Sciences, Pyzhevsky Pereulok 7, Moscow 109017 Russia

${ }^{4}$ NSF-Arizona AMS Facility, The University of Arizona, Tucson, Arizona 85721 USA
} 


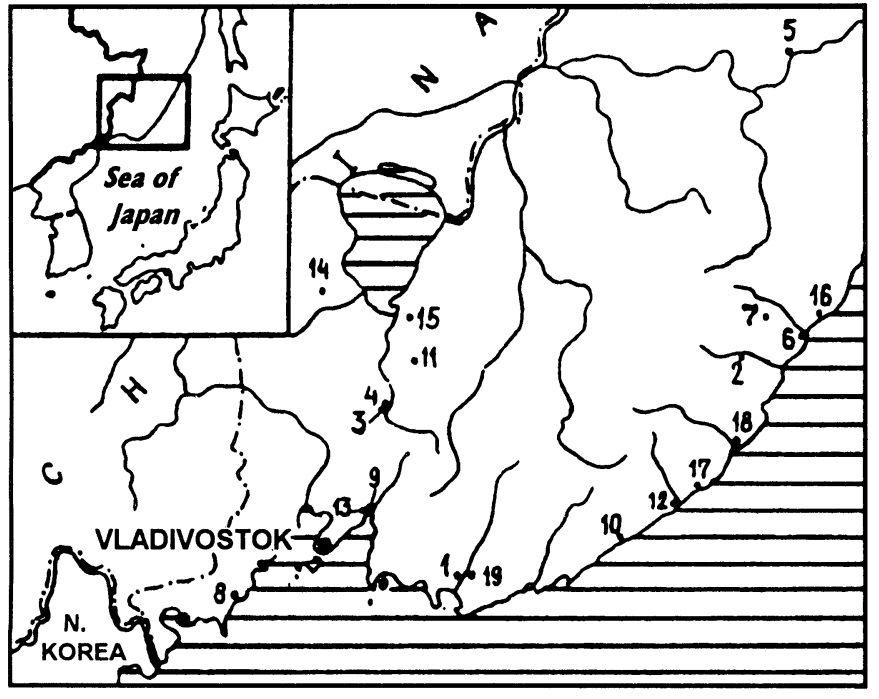

Fig. $1 .{ }^{14} \mathrm{C}$-dated sites in Primorye. Numbers correspond to those in the text: 1 . Geographical Society cave; 2 . Suvorovo 4-6; 3 . Gorbatka 3; 4. Ilistaya 1; 5. Almazinka; 6. Rudnaya; 7. Chertovy Vorota; 8. Boisman 2; 9. Oleny A; 10. Valentin-Peresheek; 11 . Mustang; 12. Phusun; 13. Kirovsky; 14. Novoselischche 4; 15 . Sinii Gai; 16. Lidovka $1 ; 17$. Eustaphy-Oleg $1 ; 18$. Sinie Skaly; 19. "Under the Linden".

3. AA-9463

Small charcoal fragments from Suvorovo 4, $25-30 \mathrm{~cm}$ below surface. Collected August 1990 by S. Gladyishev and A. Tabarev, submitted August 1992 by Y. Kuzmin.

Comment (Y.K.): Although the dates for Ki-3502 and AA-9463 are in remarkable agreement, they contradict pollen data, which show a younger age for this site, of $c a .8000-9000$ BP (Kuzmin 1992).

\section{SOAN-1922}

$13,500 \pm 200$

Humic acids from Gorbatka $3\left(43^{\circ} 57^{\prime} \mathrm{N}, 132^{\circ} 24^{\prime} \mathrm{E}\right)$, from a lens of organic-rich sediments in colluvial deposits. Collected and submitted 1980 by A. Kuznetsov.

Comment (Y.K.): the sample was collected below the artifacts at this site, which are slightly younger at $13,500 \mathrm{BP}$.

\section{Ki-3163}

$7840 \pm 60$

Charcoal from Ilistaya $1\left(43^{\circ} 57^{\prime} \mathrm{N}, 132^{\circ} 26^{\prime} \mathrm{E}\right)$ at $30-40 \mathrm{~cm}$ below surface. Collected July 1987 by A. Kuznetsov, submitted Oct 1987 by Y. Kuzmin.

General Comment: Because of the paucity of dates, the age of the Paleolithic in Primorye is still not well known. The main problem is the lack of charcoal in the Paleolithic cultural layers. The age of the Suvorovo 4 site is under discussion, and more dating of the site sediments is necessary. In general, the ${ }^{14} \mathrm{C}$ dates show that Paleolithic sites existed in Primorye during the Late Pleistocene and Early Holocene, up to $7800 \mathrm{BP}$. Editors' note: The five dates from the Paleolithic reported here also appear in Kuzmin (1994), which follows this article.

\section{THE NEOLITHIC}

\section{Rudnaya Series}

Charcoal from Tetukhe, Rudnaya Pristan $\left(44^{\circ} 21^{\prime} \mathrm{N}, 135^{\circ} 48^{\prime} \mathrm{E}\right)$.

6. GIN-5983

$7690 \pm 80$

Charcoal from the lowest layer of site, Dwelling 2, Squares A-YA/12. Collected 1985, submitted 1988 by V. Djakov. 
7. GIN-5631

$7550 \pm 60$

Charcoal from the lowest layer of site, Dwelling 2, Squares A-YA/10-11. Collected 1985 by V. Djakov, submitted 1987 by Y. Kuzmin.

\section{GIN-5984}

Charcoal from the lowest layer of site, Dwelling 2, Squares A-YA/10-11. Collected 1985, submitted 1988 by V. Djakov.

Comment (Y.K.): GIN-5631 and -5984 were collected from the same location.

9. GIN-5980

$4130 \pm 40$

Charcoal from the middle layer of site, depth $60 \mathrm{~cm}$ below surface, Dwelling 7, Squares ZH-Z/7-

8. Collected 1985, submitted 1988 by V. Djakov. Calibrated range: 2910-2435 cal BC.

10. GIN-5630

$4040 \pm 40$

Charcoal from the middle layer of site, Dwelling 8, Squares B-V/1-3. Collected 1985 by V. Djakov, submitted 1987 by Y. Kuzmin. Calibrated range: $2870-2405$ cal BC.

\section{GIN-5982}

$4030 \pm 40$

Charcoal from the middle layer of site, Dwelling 8, Squares A-D/1-2. Collected 1985, submitted 1988 by V. Djakov. Calibrated range: $2865-2400 \mathrm{cal}$ BC.

12. GIN-598

$4000 \pm 40$

Charcoal from the middle layer of site, depth $65 \mathrm{~cm}$ below surface, Dwelling 7, Squares I-K/910. Collected 1985, submitted 1988 by V. Djakov. Calibrated range: $2785-2330$ cal BC.

\section{Almazinka Series}

13. AA-9818

$7545 \pm 80$

14. AA-9817

$7430 \pm 65$

15. AA-9819

$7410 \pm 60$

Small charcoal fragments from Almazinka $\left(45^{\circ} 58^{\prime} \mathrm{N}, 135^{\circ} 46^{\prime} \mathrm{E}\right)$, depth $80-90 \mathrm{~cm}$ below surface, excavation pit 1992. Collected July 1992 by V. Lyinsha, submitted September 1992 by Y. Kuzmin.

Comment (Y.K.): Lyinsha (1992) expected the site to be Paleolithic, but 1992 excavations revealed pottery fragments (V. Lyinsha, personal communication, October 1993); thus, the site may be associated with the Neolithic.

\section{Chertovy Vorota Series}

16. SOAN-1212

$6825 \pm 45$

Animal bones from Chertovy Vorota $\left(44^{\circ} 29^{\prime} \mathrm{N}, 135^{\circ} 230^{\prime} \mathrm{E}\right)$, depth $10-80 \mathrm{~cm}$ below surface. Collected and submitted 1973 by V. Tatarnikov. Calibrated range: $6037-5377 \mathrm{cal} \mathrm{BC}$.

17. LE-4182

$6710 \pm 105$

Animal bones collected 1986 by Zh. Andreeva, submitted 1987 by Y. Kuzmin. Calibrated range: $5930-5310 \mathrm{cal} \mathrm{BC}$.

\section{SOAN-1083}

$6575 \pm 45$

Charcoal, depth $90 \mathrm{~cm}$ below surface. Collected and submitted 1973 by V. Tatarnikov. Calibrated range: $5755-5255 \mathrm{cal} \mathrm{BC}$.

19. MGU-504

$6380 \pm 70$

Charcoal collected 1973 by V. Tatarnikov, submitted 1974 by V. Stepanov. Calibrated range: 55655095 cal BC. 
20. LE-4181

$5890 \pm 45$

Animal bones collected 1986 by Zh. Andreeva, submitted 1987 by Y. Kuzmin. Calibrated range: $5070-4560 \mathrm{cal} \mathrm{BC}$.

\section{Boisman 2 series}

21. AA-9461

$6355 \pm 60$

Small charcoal fragments from the lowest layer of Boisman $2\left(42^{\circ} 47^{\prime} \mathrm{N}, 131^{\circ} 16^{\prime} \mathrm{E}\right)$, depth $95 \mathrm{~cm}$ below surface in Square G14. Collected July 1992 by A. Popov, submitted August 1992 by Y. Kuzmin. Calibrated range: 5545-5077 cal BC.

Comment (Y.K.): The sample was collected from the bottom of the cultural layer, below the shell midden.

22. AA-9460

$5330 \pm 55$

Small charcoal fragments from the lower layer of site, depth $50 \mathrm{~cm}$ in Square V7. Collected July 1992, submitted August 1992 by Y. Kuzmin. Calibrated range: 4400-3890 cal BC.

Comment (Y.K.): The sample was collected from the center of the shell midden.

\section{SOAN-3020}

$5300 \pm 215$

Animal bones from the lower layer of site in Squares A-B/13-14. Collected July 1991 by A. Popov, submitted Nov 1991 by Y. Kuzmin. Calibrated range: 4530-3685 cal BC.

Comment (Y.K.): The sample was collected from the center of the shell midden.

\section{SOAN-3019}

$5160 \pm 140$

Human bones from Burial 1, depth 130-135 cm below surface. Collected July 1991 by A. Popov, submitted Nov 1991 by Y. Kuzmin. Calibrated range: 4530-3685 cal BC.

Comment (Y.K.): The burial is associated stratigraphically with the middle of the shell midden.

\section{GIN-6957}

$5030 \pm 140$

Animal bones from the lower part of the site in Squares A-B/13-14. Collected July 1991 by A. Popov, submitted Nov 1991 by Y. Kuzmin. Calibrated range: $4120-3545$ cal BC.

Comment (Y.K.): GIN-6957 is from the same location as SOAN-3020.

\section{Oleny A Series}

26. SOAN-1549

$5370 \pm 65$

Charcoal from Layer 3, Oleny A $\left(43^{\circ} 21^{\prime} \mathrm{N}, 132^{\circ} 17^{\prime} \mathrm{E}\right), 100 \mathrm{~cm}$ below surface, Dwelling $9 \mathrm{~b}$. Collected 1965 by D. Brodiansky, submitted 1966 by A. Okladnikov. Calibrated range: $4410-3900$ cal BC.

27. SOAN-1534

$5010 \pm 30$

Charcoal from hearth, layer 3, depth $78 \mathrm{~cm}$ below surface, Dwelling $7 \mathrm{~b}$. Collected 1965 by D. Brodiansky, submitted 1966 by A. Okladnikov. Calibrated range: $3915-3360$ cal BC.

\section{Valentin-Peresheek Series}

\section{MAG-422}

$4900 \pm 200$

Charcoal from the lower layer of Valentin-Peresheek $\left(43^{\circ} 07^{\prime} \mathrm{N}, 134^{\circ} 18^{\prime} \mathrm{E}\right)$, depth $70-80 \mathrm{~cm}$ below surface. Collected and submitted 1975 by A. Garkovik. Calibrated range: $4090-3355$ cal BC.

29. MAG-398

$4500 \pm 120$

Charcoal from the lower layer of site, depth $70-80 \mathrm{~cm}$ below surface. Collected and submitted 1975 by A. Garkovik. Calibrated range: $3505-2925$ cal BC. 
30. MGU-544

$4320 \pm 90$

Charcoal from the lower layer of site, depth $100-130 \mathrm{~cm}$. Collected 1975 by A. Garkovik, submitted 1976 by V. Stepanov. Calibrated range: $3355-2665$ cal BC.

\section{Mustang Series}

31. Ki-3151

$4660 \pm 60$

Charcoal from the lower layer of Mustang $\left(44^{\circ} 09^{\prime} \mathrm{N}, 132^{\circ} 35^{\prime} \mathrm{E}\right), 80 \mathrm{~cm}$ below surface. Collected July 1987 by A. Garkovik, submitted October 1987 by Y. Kuzmin. Calibrated range: 3655-3175 cal BC.

\section{2. $\mathrm{Ki}-3152$}

$4050 \pm 70$

Charcoal from the lower layer of site, depth $50 \mathrm{~cm}$ below surface. Collected July 1987 by A. Garkovok, submitted Oct 1987 by Y. Kuzmin. Calibrated range: 2875-2405 cal BC.

\section{RUL-193}

Charcoal from Phusun (Moryak-Rybolov) $\left(43^{\circ} 20^{\prime} \mathrm{N}, 134^{\circ} 48^{\prime} \mathrm{E}\right)$. Collected and submitted 1959 by A. Okladnikov. Calibrated range: $3145-2660 \mathrm{cal}$ BC.

Comment (Y.K.): it is still unclear whether the sample was collected from the Neolithic or the Bronze Age (Derevianko 1973: 118-119; Brodiansky 1987: 114; Djakov 1992: 113-119).

\section{RUL-177}

Wood from Kirovsky $\left(43^{\circ} 20^{\prime} \mathrm{N}, 132^{\circ} 17^{\prime} \mathrm{E}\right)$. Collected and submitted 1959 by A. Okladnikov.

Comment (Y.K.): Okladnikov (1964) associated the dated cultural layer with the Bronze Age. In this layer, the earliest cultivated plant remains-millet (Setaria italica L.)-were found. A Neolithic layer is also present at the site. Calibrated range: $2925-2550 \mathrm{cal} \mathrm{BC}$.

\section{"Under the Linden" Series}

\section{SOAN-1530}

$3915 \pm 50$

Charcoal from "Under the Linden" ( $\left.42^{\circ} 56^{\prime} \mathrm{N}, 133^{\circ} 06^{\prime} \mathrm{E}\right)$. Collected and submitted 1976 by A. Okladnikov and V. Medvedev. Calibrated range: 2480-2361, 2339-2327 cal BC.

36. SOAN-1532

$3635 \pm 30$

Charcoal. Collected and submitted 1976 by A. Okladnikov and V. Medvedev. Calibrated range: 2130-2103, 2092-2073, 2054-2037, 2017-1978, 1962-1946 cal BC.

General Comment: The Rudnaya (basal layer) and the Chertovy Vorota sites are of the earliest Neolithic culture in Primorye, the Rudnaya. Together with the basal layer of the Boisman 2 site (Boisman culture) they can be attributed to the Early Neolithic. Another principal Neolithic culture in Primorye, the Zaisanovskaya, is represented by the Rudnaya (middle layer), Oleny A, ValentinPereshhek (basal layer), Mustang (basal layer) and "Under the Linden" sites. The dates of the Phusun and Kirovsky sites are chronologically close to the Zaisanovskaya culture, with which they may be associated.

\section{THE BRONZE AGE}

\section{GIN-6951}

Charcoal from Novoselischche $4\left(44^{\circ} 37^{\prime} \mathrm{N}, 131^{\circ} 47^{\prime} \mathrm{E}\right)$, from the middle layer of site, depth $40 \mathrm{~cm}$ below surface in Square T3. Collected August 1991 by N. Kluev, submitted Nov 1991 by Y. Kuzmin. Calibrated range: $1335-1254,1229-1122$ cal BC. 


\section{Sinii Gai A Series}

38. SOAN-1540

$2875 \pm 45$

Birch bark from Sinii Gai A $\left(44^{\circ} 28^{\prime} \mathrm{N}, 132^{\circ} 36^{\prime} \mathrm{E}\right)$ Layer 3, depth $60-70 \mathrm{~cm}$ below surface, Dwelling 29. Collected 1967 by D. Brodiansky, submitted 1967 by A. Okladnikov. Calibrated range: $1125-1002 \mathrm{cal} \mathrm{BC}$.

39. SOAN-1541

$2820 \pm 55$

Birch bark from Layer 3, depth 40-60 cm below surface, Dwellings 17-18. Collected 1967 by D. Brodiansky, submitted 1967 by A. Okladnikov. Calibrated range: 1034-915 cal BC.

\section{Lidovka 1 Series}

40. SOAN-1390

$2610 \pm 45$

Charcoal from Lidovka $1\left(44^{\circ} 25^{\prime} \mathrm{N}, 135^{\circ} 53^{\prime} \mathrm{E}\right)$, depth $35 \mathrm{~cm}$ below surface. Collected and submitted 1975 by V. Djakov. Calibrated range: 806-789 cal BC.

\section{SOAN-1388}

$2570 \pm 60$

Charcoal, depth $35 \mathrm{~cm}$ below surface. Collected and submitted 1975 by V. Djakov. Calibrated range: $804-764,675-662 \mathrm{cal} \mathrm{BC}$.

\section{SOAN-1424}

$\mathbf{2 5 3 0} \pm \mathbf{4 0}$

Seeds of foxtail or Japanese millet, depth 40-50 cm below surface. Collected and submitted 1976 by V. Djakov. Calibrated range: 792-759, 685-658 cal BC.

\section{SOAN-1389}

$2450 \pm 50$

Charcoal, depth $30 \mathrm{~cm}$ below surface. Collected and submitted 1975 by V. Djakov. Calibrated range: $764-678 \mathrm{cal} \mathrm{BC}$.

\section{Suvorovo 6 Series}

44. GIN-7234

$2960 \pm 90$

Charcoal from the upper layer of Suvorovo $6\left(44^{\circ} 14^{\prime} \mathrm{N}, 135^{\circ} 20^{\prime} \mathrm{E}\right)$, depth $30-40 \mathrm{~cm}$ below surface in Square K3. Collected July 1991 by A. Krupianko, submitted April 1992 by Y. Kuzmin. Calibrated range: $1370-1345,1317-1031 \mathrm{cal} \mathrm{BC}$.

\section{SOAN-3023}

Charcoal from the upper layer of the site in Square K3. Collected July 1991 by A. Krupianko, submitted November 1991 by Y. Kuzmin. Calibrated range: 1261-1068 cal BC.

\section{SOAN-3022}

Charcoal from the upper layer of site, southern part of the 1991 excavation pit. Collected July 1991 by A. Krupianko, submitted November 1991 by Y. Kuzmin. Calibrated range: 405-378 cal BC.

\section{Eustaphy-Oleg 1 Series}

\section{GIN-6948}

$3150 \pm 80$

Charcoal from Eustaphy-Oleg $1\left(43^{\circ} 28^{\prime} \mathrm{N}, 134^{\circ} 59^{\prime} \mathrm{E}\right)$, depth $50-70 \mathrm{~cm}$ below surface in Squares V/2-3, G/2-3. Collected August 1991 by A. Garkovik, submitted November 1991 by Y. Kuzmin. Calibrated range: $1519-1394,1332-1329$ cal BC.

\section{GIN-6949}

$2900 \pm 120$

Charcoal from the lower part of the cultural layer, depth $80-90 \mathrm{~cm}$ below surface. Collected August 1991 by A. Garkovik, submitted November 1991 by Y. Kuzmin. Calibrated range: 1300-920 cal BC. 
49. MGU-542

$2840 \pm 170$

Charcoal from the lower layer of the site at Sinie Skaly $\left(43^{\circ} 44^{\prime} \mathrm{N}, 135^{\circ} 14^{\prime} \mathrm{E}\right)$, depth $80-100 \mathrm{~cm}$ below surface. Collected 1976 by $\mathrm{Zh}$. Andreeva, submitted 1977 by V. Stepanov. Calibrated range: $1260-830 \mathrm{cal} \mathrm{BC}$.

General Comment: Krushanov (1989) subdivided the Bronze Age of Primorye into three cultures: Sinegaiskaya (Sinii Gai, Layer 3; Novoselischche 4), Lidovskaya (Lidovka 1; Suvorovo 6, upper layer) and Margaritovskaya (Sinie Skaly, lower layer; Eustaphy-Oleg 1). All these cultures follow the Neolithic and are close to one another chronologically.

\section{Discussion AND CONCLUSION}

We have estimated for these series of dates the weighted mean age (WMA) (Aitken 1990). The WMA of the 3 dates at the Almazinkasite is $7450 \pm 40 \mathrm{BP}$; of the 3 dates for Rudnaya (lower layer), $7560 \pm 45 \mathrm{BP}$; of the 4 dates for the Rudnaya (middle layer), $4050 \pm 20 \mathrm{BP}$, i.e., $2865-2415 \mathrm{cal} \mathrm{BC}$; of the 2 dates for Sinii Gai (layer 3), $2855 \pm 35 \mathrm{BP}$, i.e., 1082-977 cal. BC; and of the 4 dates for Lidovka 1, $2540 \pm 25$ BP, i.e., 792-765, 677-661, 606-604 cal BC.

Based on the chronological difference between the Rudnaya and Zaisanovskaya cultures, we establish the Zaisanovskaya as a Late Neolithic culture. The ${ }^{14} \mathrm{C}$ age of the oldest shell midden on the Pacific coast of the Russian Far East, Boisman 2 (lower layer), is close to the age of the Early Neolithic shell midden at Tongsamdong in Korea (5890 140 BP; GX-0378) (Nelson 1991).

Using the WMA as a reference point together with all the ${ }^{14} \mathrm{C}$ dates (Fig. 2), one can establish both the boundaries and the duration of archaeological periods and cultures. The transition from the Pale-

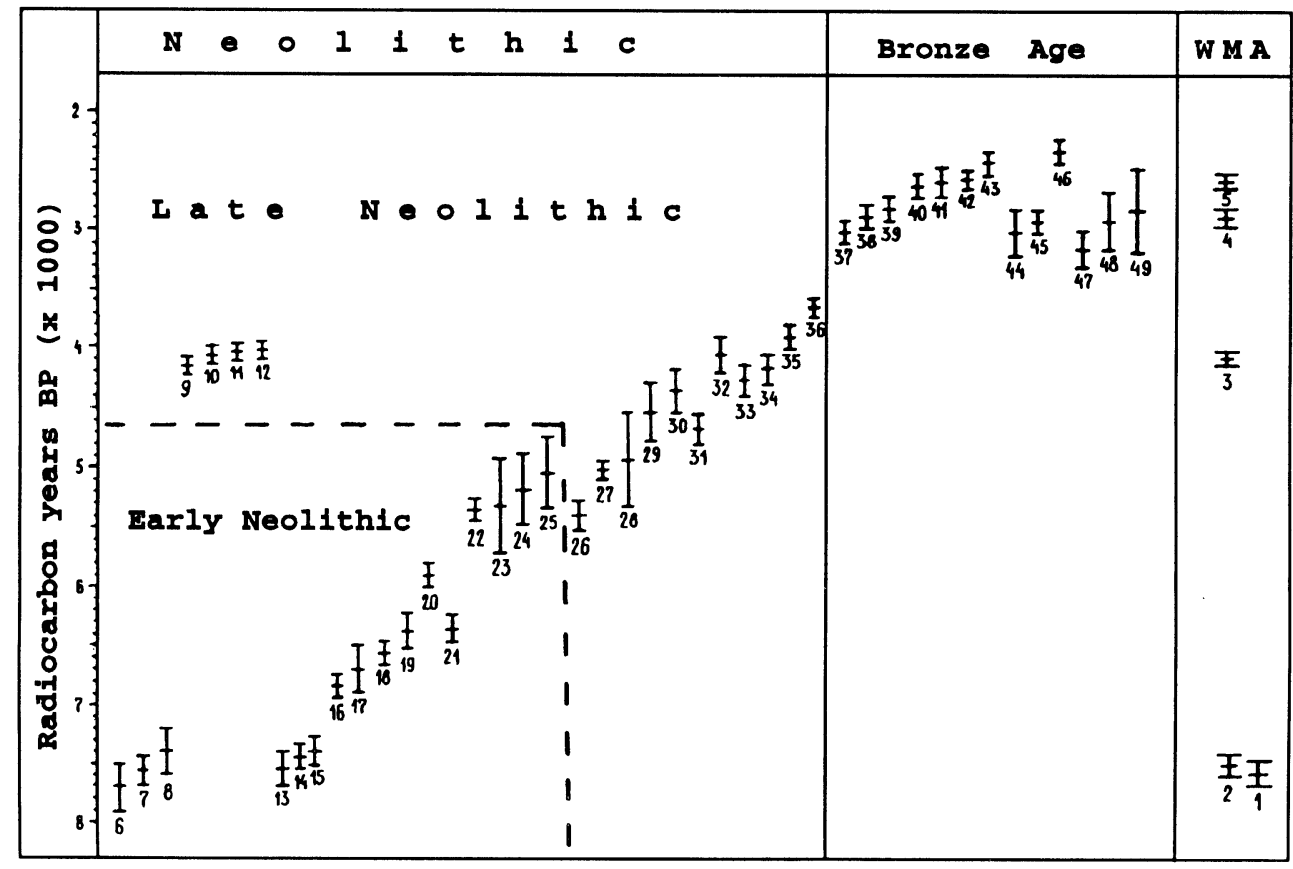

Fig. $2{ }^{14} \mathrm{C}$ sequence of the Neolithic and Bronze Ages of Primorye. Numbers correspond to those in the text; dates are plotted with two sigma errors. WMA: 1. Rudnaya (lower layer); 2. Almazinka; 3. Rudnaya (middle layer); 4. Sinii Gai A, Layer 3; 5. Lidovka 1. 
olithic to the Early Neolithic occurred ca. 7800-7900 BP. The Early Neolithic Rudnaya and Boisman cultures existed up to $5000 \mathrm{BP}$; the Rudnaya to 7600-5900 BP, and the Boisman to 6400-5000 BP. The Early Neolithic gave way to the Late Neolithic at $c a$. 5300-5000 BP. The Zaisanovskaya culture existed between 5300-3600 BP. We can also place the boundary between the Late Neolithic and Bronze Age at ca. $3000 \mathrm{BP}$, but no known Zaisanovskaya sites are dated between 3600 and $3000 \mathrm{BP}$. The Bronze Age cultures date from 3000-2300 BP.

The first interpretation of ${ }^{14} \mathrm{C}$ dates of the ancient cultures from Primorye presented here show that we must continue to date these sites and cultures, and establish the age of the Paleolithic/Neolithic transition and the Late Neolithic/Bronze Age boundary.

\section{ACKNOWLEDGMENTS}

The authors thank the following individuals for helpful discussions of the results and for providing us with information: Zh. Andreeva, D. Brodiansky, A. Garkovik, S. Gladyishev, V. Djakov, N. Kluev, A. Krupianko, A. Kuznetsov, V. Lyinsha, N. Ovodov, A. Popov, V. Stepanov, A. Tabarev, R. Vasijevsky. The dating of the Arizona AA- samples was partially funded by U.S. NSF Grant EAR $92-$ 03883. We thank L. J. Toolin and A. L. Hatheway for technical assistance in these measurements. We also thank N. Mishchenko for helping to prepare the manuscript.

\section{REFERENCES}

Aitken, M. J. 1990 Science-Based Dating in Archaeology. London, Longman: $274 \mathrm{p}$.

Brodiansky, D. L. 1987 An Introduction to Far Eastern Archaeology. Vladivostok, Far Eastern University Press: 276 p. (in Russian).

Derevianko, A. P. 1973 The Early Iron Age of the Amur River Basin. Novosibirsk, Nauka: 355 p. (in Russian).

Djakov, V. I. 1992 The Multilayered Settlement Rudnaya Pristan and the Periodization of the Neolithic Cultures in Primorye. Vladivostok, Dalnauka: 140 p. (in Russian).

Klein, J., Lerman, J. C., Damon, P. E. and Ralph, E. K. 1982 Calibration of radiocarbon dates: Tables based on the consensus data of the Workshop on Calibrating the Radiocarbon Time Scale. Radiocarbon 24 (2): 103-150.

Krushanov, A. I., ed., 1989 The History of the USSR Far East From Prehistory Up to the 17th Century. Moscow, Nauka: 376 p. (in Russian).

Kuzmin, Y. V. 1992 Geoarchaeological study of the Late Paleolithic sites in Primorye, Far East Russia. Nihon Daigonki Gakkai [Quaternary Research] 31 (4): 243254.
Lyinsha, V. A. 1992 The discovery of the Paleolithic in Northern Primorye. In Paleoecology and Human Settlement in Northern Asia and America. Abstracts of the International Symposium. Krasnoyarsk, Institute of Archaeology and Ethnography: 168-171 (in Russian).

Nelson, S. M. 1991 Korean archaeological sequences from the first ceramics to the introduction of iron. In Ehrich, R.W., ed., Chronologies in Old World Archaeology, 3rd edition. Chicago, University of Chicago Press: 418-424, 430-438.

Okladnikov, A. P. 1964 The Soviet Far East in the light of modern achievements of archaeology. Voprosy Istorii 1: 44-57 (in Russian).

Stuiver, M. and Pearson, G. W. 1986 High-precision calibration of the radiocarbon time scale, AD 1950-500 BC. In Stuiver, M. and Kra, R. S., eds., Proceedings of the 12 th International ${ }^{14} \mathrm{C}$ Conference. Radiocarbon 28 (2B): 805-838.

Vasiljevsky, R. S. 1987 The Upper Paleolithic cultures of the southeastern Primorye. In Vasiljevsky, R. S., ed., The Prehistory of Siberia and the Far East. Novosibirsk, Nauka: 103-106 (in Russian). 